\title{
Peranan Lembaga Keuangan Credit Union Kasih Sejahtera Bagi Petani di Kabupaten Timor Tengah Utara
}

\author{
Marsianus Falo , Simon Juan Kune \\ ${ }^{a}$ Fakultas Pertanian, Universitas Timor, Kefamenanu, Indonesia. \\ ${ }^{b}$ Fakultas Pertanian, Universitas Timor, Kefamenanu, Indonesia.
}

\section{Article Info}

Article history:

Received 18 November 2016

Received in revised form 24 November 2016 Accepted 7 Januari 2017

\section{Keywords:}

Credit Union

Lembaga Keuangan

Kasih Sejahtera

\section{Abstrak}

Penelitian ini bertujuan untuk: 1) mengetahui gambaran Credit Union Kasih Sejahtera Cabang Kefamenanu Kabupaten TTU, 2) mengetahui peranan Credit Union Kasih Sejahtera Cabang Kefamenanu bagi petani di Kabupaten TTU. Pengumpulan data dilakukan mengounakan metode survei. Dari hasil penelitian diketahui bahwa Credit Union Kasih Sejahtera adalah lembaga keuangan yang menjalankan usaha simpan pinjam serta memiliki 3 ciri utama yang menjadi keunikannya yakni ciri bank, ciri koperasi, serta ciri asuransi. Ada upaya pemberdayaan dari Credit Union bagi petani yang bertujuan untuk mengubah pola pikir petani yang bersifat konsumtif atau boros menjadi petani yang hemat serta mampu mengelola keuangannya secara mandiri dan terarah melalui pendidikan dan pelatihan yang berlangsung secara kontinyu. Produk-produk yang dimiliki oleh Credit Union Kasih Sejahtera bersifat memudahkan serta membantu anggota khususnya petani dalam rangka meningkatkan kesejahteraan serta derajat hidupnya. Peranan nyata Credit Union Kasih Sejahtera bagi petani di antaranya adalah sebagai penyedia dana segar dengan bunga yang rendah sehingga dapat dimanfaatkan oleh petani untuk dapat membiayai pendidikan anak, membangun rumah yang layak huni, serta memenuhi kebutuhan-kebutuhan lainnya. Credit Union juga berperan merubah pola pikir petani agar hidup hemat dan mulai menabung demi masa depan. (02017 dipublikasikan oleh Agrimor.

\section{Pendahuluan}

Lembaga keuangan adalah salah satu penopang utama dalam pembangunan nasional. Sebab sasaran utama dari lembaga keuangan adalah pembangunan $\mathrm{d}$ bidang ekonomi dan merupakan bagian yang tak dapat dipisahkan dari pembangunan nasional (Triandaru dan Santoso, 2006). Lembaga keuangan di Indonesia terdiri atas dua bentuk yaitu lembaga keuangan bank dan lembaga keuangan non-bank. Lembaga keuangan bank terdiri atas bank sentral, bank umum, dan bank perkreditan rakyat, sedangkan lembaga keuangan non-bank terdiri atas lembaga-lembaga keuangan di luar bank yang salah satunya adalah koperasi (Kasmir, 2007).

Koperasi sebagai salah satu lembaga keuangan non-bank, sangat penting peranannya dalam upaya memupuk pertumbuhan ekonomi serta meningkatkan kesadaran, peran dan tanggungjawab masyarakat (Funan, 2010). Koperas dikenal di Indonesia sebagai salah satu pelaku ekonomi terhadap pembangunan di samping BUMN dan swasta. Koperasi kredit adalah koperasi yang beroperas di bidang pemberian kredit kepada para anggota dengan bunga yang serendahrendahnya. Salah satu bentuk koperasi kredit yang mulai berkembang di Indonesia adalah Credit Union. Credit Union adalah sebuah lembaga keuangan yang bergerak di bidang simpan pinjam yang dimiliki dan dikelola oleh anggotanya dan bertujuan untuk mensejahterakan anggotanya sendiri. Koperas Kredit atau Credit Union memang unik dan sangat menarik untuk dikaji bahkan dicurigai oleh pihak-pihak yang tidak paham atau baru mengenal.

Salah satu Credit Union yang saat ini mulai berkembang pesat adalah Credit Union Kasih Sejahtera. Credit Union Kasih Sejahtera didirikan pada tanggal 8 Juni 2007 di Emaus Atambua melalui proses Perencanaan Strategis (Renstra) bimbingan tim BKCU Kalimantan. Credit Union menerapkan prinsip-prinsip yang berlaku di tingkat Lokal, Nasional, dan Internasional. Prinsip dari Credit Union ini adalah: 1) Keanggotaan bersifat terbuka dan sukarela, 2) Kontro dilakukan secara demokratis oleh anggota, 3) Tidak diskriminatif, 4) Pelayanan dan distribusi yang baik terhadap anggota, 5) Membangun stabilitas keuangan, 6) Pendidikan yang terus-menerus, 7) Membangun kerjasama antar Credi Union, dan 8) Tanggung jawab sosial. Tujuan dari Credit Union Kasih Sejahtera adalah : 1) Membimbing dan mengembangkan sikap menghemat diantara anggota untuk menabung, 2) Mengembangkan asset anggota secara bersamasama, 3) Memberikan pelayanan pinjaman yang layak, terarah, dan bijaksana bagi anggota, 4) Mengadakan pendidikan dan pelatihan secara terus-menerus bagi anggota, pengurus, dan manajemen.

Credit Union Kasih Sejahtera sebagai lembaga keuangan non-bank yang formal memiliki produk simpanan maupun produk pinjaman. Produk-produk simpanan terdiri dari : 1) Simpanan Saham terdiri dari (a) Simpanan Pokok, (b) Simpanan Wajib, 2) Simpanan Non-saham yang terdiri dari : (a) Fini adalah simpanan pensiun yang diperlakukan setara simpanan saham, (b) Sufa adalah simpanan bunga harian, 3) Simpanan Berjangka yang diberi nama Lopo atau lumbung, 4) Simpanan perumahan, 5) Simpanan pendidikan. Sedangkan produkproduk pinjaman terdiri dari kredit kapitalisasi (pinjaman untuk disimpan sebagai modal), kredit usaha produktif, kredit konsumtif, kredit kendaraan bermotor, kredit kepemilikan rumah, serta kredit pertanian.

Credit Union cabang Kefamenanu Kabupaten Timor Tengah Utara adalah termasuk koperasi kredit oleh karenanya pendidikan terhadap anggota maupun pengurus selalu dikedepankan sehingga masing-masing dapat mengetahui dan memahami hak serta kewajibannya. Hingga saat ini jumlah anggota dari Credi Union Cabang Kefamenanu telah mencapai 4.409 orang. Anggota dari Credi Union sendiri terdiri dari berbagai macam latar belakang profesi serta agama, dengan kata lain setiap orang berkesempatan untuk menjadi anggota dari Credit Union asalkan memiliki watak serta sifat yang baik sebab keanggotaan di Credi Union sangat mengandalkan kepercayaan di antara sesama anggota. Credi Union memiliki ciri-ciri koperasi yang umum seperti pendidikan dan pelatihan bagi anggota dan perangkat pengurus yang lain, Credit Union juga memiliki ciriciri bank serta ciri-ciri asuransi yang terlihat dari berbagai produk simpanan serta produk pinjamannya.
Dilihat dari berbagai produk dan ciri-ciri Credit Union tersebut, ternyata sangat berpihak terhadap masyarakat yang berekonomi lemah khususnya petani. Namun, tidak dapat dipungkiri bahwa kehidupan masyarakat petani khususnya di Kabupaten TTU belum menunjukkan perubahan yang memuaskan. Tujuan penelitian ini adalah untuk mengetahui gambaran Credit Union Kasih Sejahtera Cabang Kefamenanu Kabupaten TTU serta mengetahui peranan Credit Union Kasih Sejahtera Cabang Kefamenanu bagi petani di Kabupaten TTU.

\section{Metode}

Penelitian telah dilakukan di Credit Union Cabang Kefamenanu, Kecamatan Kota Kefamenanu, Kabupaten TTU mulai Bulan Februari sampai dengan Apri 2013. Metode pengambilan sampel adalah metode quota sampling dengan memilih 20 orang yang terdiri dari pengurus 5 orang, pengelola/manajer 1 orang, karyawan/staf 4 orang, anggota 10 orang dengan dasar pertimbangan mudah dihubungi, mampu memberikan penjelasan dan bersedia untuk memberikan data. Data dikumpulkan melalui metode survey, jenis data yang dikumpulkan berupa data primer dan sekunder dimana data primer diperoleh dari wawancara langsung dengan responden, berdasarkan daftar pertanyaan yang disiapkan. Sedangkan data sekunder diperoleh dari instansi-instansi terkait yang ada hubungannya dengan penelitian ini. Untuk mengetahui gambaran dan dampak Credit Union Kasih Sejahtera Cabang Kefamenanu dapat digunakan analisis deskriptif sesuai petunjuk (Nasir, 2003).

\section{Hasil dan Pembahasan}

3.1 Gambaran Umum Credit Union Kasih Sejahtera Tempat Pelayanan Kefamenanu

Pada tahun 2009, Credit Union Kasih Sejahtera resmi membuka Tempa Pelayanan (TP) Kefamenanu tepatnya di samping gereja Sta. Theresia. Hal in bertujuan untuk semakin mendekatkan pelayanan kepada anggota di Kabupaten Timor Tengah Utara. Dibukanya Credit Union Kasih Sejahtera Tempa Pelayanan Kefamenanu tentunya disambut antusias masyarakat khususnya petani di Kabupaten Timor Tengah Utara (Deprindakop, 2010).

Jenis usaha yang dijalankan oleh Credit Union Kasih Sejahtera Tempat Pelayanan Kefamenanu adalah usaha simpan pinjam dengan lembaga penjamin simpanan pada Credit Union Kasih Sejahtera adalah Badan Koordinasi Credit Union Kalimantan (BKCUK) yang berkedudukan di Kalimantan. Ketentuan umum pelayanan pinjaman meliputi:

1. Yang boleh mengajukan pinjaman adalah anggota biasa yang telah menabung secara aktif setidaknya selama 3 bulan dan sudah mengikuti Pendidikan Dasar secara penuh terkecuali pinjaman Pinta,

2. Anggota Luar biasa (anak-anak umur di bawah 17 tahun dan belum menikah) Tidak boleh meminjam,

3. Pemohon pinjaman mengisi Surat Permohonan Pinjaman (SPP), pemohon berkonsultasi (wawancara) langsung dengan Bagian Kredit pada jam kerja,

4. Surat Permohonan Pinjaman yang diajukan harus ditandatangani minimal 2 orang penjamin

5. Membawa kelengkapan administrasi antara lain: a) foto copy KTP suami/istri, b) foto copy sertifikat Pendidikan Dasar, c) foto copy kartu keluarga, d) rekening listrik bulan terakhir, e) slip/struk pembayaran gaji bulan terakhir, f) foto copy bukti kepemilikan barang jaminan yang ditawarkan, g) foto copy bukti pembayaran Pajak Bumi dan Bangunan.

6. Suami/isteri wajib mengetahui dan menandatangani SPP yang diajukan Menjadi saksi berarti menjadi penjamin (ikut bertanggungjawab) penuh atas pinjaman.

7. Pinjaman di bawah simpanan atau sebesar simpanan, langsung dicairkan dan tidak perlu penjamin tetapi tetap melalui analisa $5 \mathrm{C}$

8. Pinjaman pertama diutamakan untuk Pinta.

9. Pinjaman pertama yang bukan Pinta maksimal sebesar Simpanan

10. Pinjaman kedua dan seterusnya dapat diberikan jika pinjaman Pinta dan pinjaman pertama telah lunas minimal $50 \%$. 
11. Pinjaman selanjutnya setelah point 8 s.d 9 lunas; dapat meminjam maksimal $50 \%$ di atas simpanannya tetapi tidak boleh melebihi Plafon pinjaman.

12. Jaminan Pinjaman adalah simpanannya.

13. Perjanjian Pinjaman menggunakan MATERAI, kecuali Pinta tahap pertama.

14. Jasa Pelayanan $1 \%$ dari pinjaman yang dicairkan.

15. Denda $3 \%$ dari (angsuran tertunggak ditambah bunga tertunggak).

16. Pembayaran pokok pinjaman dan bunga pinjaman dikenakan jangka waktu jatuh tempo dengan toleransi paling lama 5 hari.

17. Pencairan pinjaman hanya dapat dilakukan sampai dengan tanggal 25 dalam bulan, kecuali pinjaman setara simpanan dan Pinta.

18. Sistem pengembalian pinjaman dapat menggunakan Setoran Biasa/Setoran Tetap.

19. Pengajuan pinjaman baru dilakukan setelah pinjaman lama dilunasi minima $50 \%$.

20. Besar pinjaman yang dikabulkan menjadi wewenang bagian kredit berdasarkan hasil penelitian terhadap Capacity Based Lending (CBL) dan analisa 5C (capacity/kemampuan mengembalikan, character/watak, capital/modal, condition/kondisi, dan collateral/jaminan).

Jumlah asset Credit Union Kasih Sejahtera Tempat Pelayanan (TP) Kefamenanu sampai dengan 30 April 2012 sebesar: Rp. 45.931.629.754. Sedangkan jumlah anggota Credit Union Kasih Sejahtera Tempat Pelayanan (TP) Kefamenanu per 30 April 2012 sebanyak: 4.588 orang (Credit Union, 2010). Credit Union Kasih Sejahtera TP Kefamenanu sebagai lembaga keuangan yang diakui dan memiliki nomor badan hukum, memiliki jalinan kerjasama dengan semua instansi pemerintahan dan lembaga keuangan bank. Bentuk kerjasama yang dijalin dengan instansi pemerintahan diantaranya, 1) berkoordinasi dengan instansi pemerintahan yang bersangkutan mengenai kegiatan-kegiatan yang akan dijalankan oleh Credit Union Kasih Sejahtera, 2) berkoordinasi dengan bendahara di setiap instansi pemerintahan dalam hal pemotongan gaji PNS yang bertugas di instansi tersebut dan memiliki pinjaman pada Credit Union Kasih Sejahtera. Sedangkan bentuk kerjasama dengan lembaga keuangan bank yaitu berkoordinasi dengan lembaga keuangan bank dalam hal mengamankan asset Credit Union Kasih Sejahtera pada bank yang ditunjuk. Lembaga keuangan bank yang memiliki hubungan kerjasama dengan Credit Union Kasih Sejahtera TP Kefamenanu adalah Bank Rakyat Indonesia (BRI) dan Bank Pembangunan Daerah (BPD).

Produk-produk yang dimiliki oleh Credit Union Kasih Sejahtera Tempat Pelayanan (TP) Kefamenanu antara lain simpanan, pinjaman dan pelayanan non simpan-pinjam.

\section{A Simpanan}

\section{A.1 Simpanan Saham}

Simpanan saham: simpanan Pokok Rp. 1.000.000,- per anggota, Simpanan Wajib Rp. 5.000,- per bulan, per anggota, Balas Jasa Simpanan (BJS) 14\% per tahun, bagi anggota aktif, Balas Jasa Simpanan (BJS) bagi anggota tidak aktif ditetapkan oleh Pengurus, BJS dibukukan setahun sekali setelah RAT, Diikutsertakan dalam program JALINAN (Jaminan Perlindungan Kalimantan) Puskopdit BKCU Kalimantan, Dijadikan jaminan pinjaman, Selama menjadi anggota, Simpanan Saham tidak dapat ditarik, Penggantian buku yang hilang dikenakan biaya Rp 5.000,-

\section{A.2 Simpanan Non Saham}

\section{- $\quad$ Fini (Simpanan Investasi: Benih Unggul)}

FINI adalah Simpanan yang diperuntukkan sebagai dana pensiun yang diperlakukan setara Simpanan Saham: Simpanan perdana dan saldo minimal Rp. 1.000.000,- (satu juta rupiah), simpanan perdana secara tunai maksimal Rp. 5.000.000,- (lima juta rupiah), kecuali melalui Pinta, Setoran tunai selanjutnya maksimal Rp. 500.000,- per bulan, kecuali melalui Pinta, Bagi anggota yang menabung Rp. 10.000,- s.d Rp. 500.000,- dan tidak ada penarikan mendapat BJS $14 \%$ per tahun, Jika ada penarikan maka BJS $3 \%$ per tahun pada bulan yang bersangkutan, Jika tidak ada penarikan dan atau tidak menabung maka BJS $8 \%$ per tahun dalam bulan bersangkutan, Jika menabung kurang dari Rp 10.000, maka BJS $11 \%$ per tahun dalam bulan bersangkutan, Bagi anggota yang telah memiliki FINI Rp 100.000.000,- maka aturan 1.4 - 1.7 tidak berlaku dan BJS tetap dihitung $14 \%$ per tahun, Anggota yang sudah memiliki saldo Simpanan FINI Rp 100.000.000,- BJS nya dapat ditarik, BJS dibukukan setiap akhir bulan, FINI diikutsertakan dalam program JALINAN (Jaminan Perlindungan Kalimantan), Puskopdit BKCU Kalimantan, Pergantian buku yang hilang dikenakan biaya Rp 5.000,-

\section{- Sufa (Bunga)}

SUFA adalah simpanan bunga harian: Balas Jasa SUFA 4\% per tahun dan sewaktu - waktu dapat berubah, Dapat disetor atau ditarik kapan saja pada saat jam kerja, Penarikan SUFA tidak dapat diwakilkan, kecuali dengan Surat Kuasa bermeterai dari yang bersangkutan, Saldo minimal Rp. 25.000,-Bunga dibukukan setiap akhir bulan, Simpanan ini tidak diikutsertakan dalam program JALINAN, Pergantian buku yang hilang dikenakan biaya administrasi Rp 5.000,-, Penutupan rekening SUFA dikenakan biaya administrasi Rp. 10.000,-

\section{A.3 Simpanan Berjangka/Lopo (Lumbung)}

LOPO adalah simpanan bunga berjangka, setoran minimal Rp 500.000,-, jangka waktu penyimpanan: 1) 3 bulan $=5 \%$ p.a (per tahun); 2) 6 bulan $=6 \%$ p.a (per tahun); 3) 12 bulan $=7 \%$ p.a (per tahun). LOPO tidak dapat dipindahtangankan, bunga LOPO dibukukan di rekening SUFA setiap tanggal jatuh tempo, pencairan LOPO sebelum jatuh tempo dikenakan pinalti (biaya administrasi) $4 \%$ dari jumlah pencairan, pencairan LOPO tidak dapat diwakilkan, kecuali dengan Surat Kuasa bermeterai dari yang bersangkutan, bila penyimpan LOPO meninggal dunia, penarikan simpanan dilakukan oleh ahli waris yang sah, tidak diikutsertakan dalam program JALINAN

\section{A.4 Simpanan Perumahan ( Simperum CU)}

Tujuannya adalah membantu anggota merancang atau mempersiapkan modal untuk membangun atau merenovasi rumah dan untuk pembelian (kepemilikan) rumah atau tanah. Syarat-syarat: 1) Balas jasa simpanan $8 \%$ p.a dan dibukukan setiap akhir bulan, 2) Pemilik rekening simpanan adalah anggota penuh CU Kasih Sejahtera, 3) Setoran awal untuk membuka rekening simpanan dan saldo minimal adalah Rp. 100.000,- dan setoran selanjutnya minimal Rp. 10.000,- per bulan., 4) Simpanan dapat ditarik apabila telah mencapai saldo Rp. 5.000.000,- dan mengendap minimal 12 bulan, 5) Penarikan simpanan yang tujuannya bukan untuk pembelian rumah/renovasi rumah dan pembelian tanah dikenakan sanksi $2 \%$ dari jumlah yang ditarik apabila simpanan sudah mengendap lebih dari 12 bulan, 6) Penarikan simpanan yang belum mengendap 12 bulan dikenakan sanksi 5\% dari jumlah penarikan, 7) Apabila penarikan simpanan melebihi saldo minimal maka rekening anggota langsung ditutup dan dikenakan sanksi $2 \%$ dari jumlah saldo simpanan, 8) Penarikan simpanan perumahan maksimal 3 kali dalam setahun, 9) Simpanan perumahan dapat dijadikan jaminan dan syarat untuk mengajukan Pinjaman Kepemilikan Rumah atau Tanah, 10) Diikutsertakan dalam program JALINAN, 11) Apabila dijadikan sebagai jaminan Pinjaman Perumahan maka simpanan tidak dapat ditarik.

\section{A.5 Simpanan Pendidikan}

Tujuannya untuk membangun dan menanamkan kebiasaan menabung bagi pelajar/mahasiswa sejak dini serta membantu meringankan biaya sekolah (biaya pendaftaran, uang semester, buku, pakaian seragam, dll) dengan menyisihkan sebagian uang jajan. Syarat-syarat: 1) Balas jasa simpanan $6 \%$ p.a dan dibukukan setiap akhir bulan, 2) Penabung wajib menambahkan saldo simpanannya minimal Rp. 10.000,- dan maksimal Rp. 100.000,- per bulan., 3) Setoran awa untuk membuka rekening simpanan adalah Rp. 25.000,-, 4) Jenis simpanan in tidak terbatas hanya bagi anggota, tetapi ditujukan juga kepada para pelajar atau mahasiswa yang belum menjadi anggota, 5) Simpanan hanya dapat ditarik untuk biaya pendidikan, maksimal $1 \mathrm{kali} / \mathrm{bulan}, 6)$ Masa keanggotaan hanya sampai pada usia anggota/penabung maksimal 24 tahun, apabila usia melebihi batasan maka rekening ditutup secara otomatis, 7) Jika terjadi penarikan lebih dari 1 kali per bulan dikenakan pinalti $3 \%$ dari jumlah yang ditarik, 8) Buka rekening bag penabung (non anggota) dikenakan biaya administrasi buku Rp. 5.000,-, 9) Jika buku hilang atau rusak, dikenakan biaya administrasi penggantian buku Rp $5.000,-$, 10) Dikenakan biaya administrasi tutup rekening Rp.10.000,-, 11) Simpanan tidak diikutsertakan dalam program JALINAN BKCU Kalimantan.

\section{B Pinjaman}

\section{B.1 Kredit Pinta (PINjaman mengembangkan TAbungan)}

Tujuannya adalah membangun kebiasaan menabung dan memperbesar tabungan menuju kebebasan finansial. Hanya mereka yang mempunyai simpanan yang dapat bertahan hidup pada masa-masa sulit. Syarat-syarat: 1 ) Pinjaman dicairkan pada saat pengajuan pinjaman, 2) Setiap anggota baru wajib PINTA minimal Rp. 2.000.000,- dan maksimal Rp. 20.000.000,- dengan jangka waktu pengembalian minimal 6 bulan dan maksimal 36 bulan, 3) Plafon Pinta tahap kedua dan seterusnya maksimal Rp. 25.000.000., dengan jangka waktu pengembalian minimal 6 bulan dan maksimal 60 bulan, 4) Balas jasa pinjaman $1,75 \%$ menurun per bulan atau $21 \%$ p.a., 5) Jasa pelayanan $1 \%$ dari pinjaman cair, 6) Apabila 3 bulan berturut-turut tidak mengangsur, maka anggota yang bersangkutan akan dikeluarkan dari keanggotaan (pinjaman PINTA perdana saat menjadi anggota baru), 7) Apabila pinjaman PINTA tahap kedua dan seterusnya tidak diangsur setelah jatuh tempo dan masa toleransi 5 hari maka Staf Manajemen dapat menarik Simpanan Fini untuk mengangsur dan membayar balas jasa pinjaman, 8) Simpanan Fini dijadikan jaminan pinjaman, artinya selama pinjaman belum lunas maka anggota yang bersangkutan tidak dapa menarik Simpanan Fini, 9) Pinjaman diikutsertakan dalam program JALINAN. B.2 Kredit Kendaraan Bermotor

Tujuannya adalah membantu anggota memenuhi kebutuhan kepemilikan kendaraan bermotor berupa sepeda motor maupun mobil baik untuk kebutuhan pribadi maupun tujuan usaha. Syarat-syarat: 1) Tidak untuk tujuan uang muka kredit di dealer, 2) Pencairan pinjaman dilakukan oleh staf bagian kredit dengan membayarkan langsung ke dealer motor atau mobil, 3) Plafon pinjaman maksimal Rp. 350.000.000., 4) Memiliki jaminan tabungan yang riil (Simpanan Saham + Simpanan Fini dikurangi sisa pinjaman) sebesar 25\% dari harga kendaraan yang dibeli, 5) Kendaraan tersebut diasuransikan (asuransi kecelakaan, asuransi kehilangan) dan nominalnya ditambahkan pada pinjaman. BPKB dari kendaraan tersebut harus atas nama peminjam, dan disimpan oleh CU Kasih Sejahtera sebagai barang jaminan, 6) BPKB dari kendaraan akan dikembalikan kepada anggota (peminjam) setelah pinjamannya lunas, 7) Lamanya pengembalian pinjaman maksimal 60 (enam puluh) bulan, 8) Balas jasa pinjaman 1,8\% menurun per bulan, 9) Jasa pelayanan 1\% dari pinjaman yang dicairkan, 10) Pinjaman diikutsertakan dalam program JALINAN.

\section{B.3 Kredit Kepemilikan Rumah}

Tujuannya adalah membantu anggota untuk membangun rumah, membeli rumah, dan membeli tanah. Syarat-syarat: 1) Berlaku bagi anggota yang suam dan istri telah menjadi anggota CU Kasih Sejahtera, kecuali yang tidak/belum menikah, 2) Rumah yang dibangun/dibeli menjadi jaminan pinjaman dan diasuransikan (asuransi kebakaran) sesuai jangka waktu pengembalian pinjaman, 3) Jangka waktu pengembalian pinjaman maksimal 120 bulan, 4) Plafon 
pinjaman maksimal Rp. 150.000.000,-, 5) Jaminan pinjaman diikat oleh notaris, biaya notaris ditanggung peminjam, 6) Memiliki simpanan perumahan minimal $25 \%$ dari pinjaman yang dicairkan dan barang berharga lainnya bila diperlukan, 7) Bunga pinjaman $1,75 \%$ menurun per bulan atau $21 \%$ p.a, 8) Jasa pelayanan $1 \%$ dari pinjaman cair, 9) Pinjaman diikutsertakan dalam program JALINAN.

\section{B.4 Kredit Pertanian}

Tujuannya adalah membiayai usaha agrobisnis atau budi daya komoditi pertanian jangka pendek seperti: padi, jagung, dll, termasuk peternakan dan usaha ikan air tawar bagi petani dengan memperhatikan usaha pertanian yang ramah lingkungan. Syarat-syarat: 1) Balas jasa pinjaman dibayar dimuka, 2) Plafon pinjaman maksimal Rp. 10.000.000,-, 3) Pelunasan pinjaman dilakukan setelah panen, 4) Balas jasa pinjaman sebesar $1 \%$ tetap per bulan atau $12 \%$ p.a, 5) Memiliki jaminan tabungan yang riil ( Simpanan Saham + Simpanan Fin dikurangi sisa pinjaman) sebesar $20 \%$ dari jumlah pinjaman yang dicairkan, 6 ) Bersedia dikunjungi, dipantau dan dibina oleh staf dari CU Kasih Sejahtera, 7) Jasa pelayanan $1 \%$ dari saldo pinjaman yang dicairkan, 8) Pinjaman diikutsertakan dalam program JALINAN.

\section{B.5 Kredit Usaha Produktif Umum}

Tujuannya adalah diperuntukan bagi anggota yang ingin membuka usaha atau ingin mengembangkan usahanya dalam rangka meningkatkan modal usaha. Syarat-syarat: 1) Plafon kredit usaha produktif umum maksimal Rp. 150.000.000,-, 2) Memiliki jaminan tabungan yang riil (Simpanan Saham + Simpanan Fini dikurangi sisa pinjaman) sebesar $25 \%$ dari jumlah pinjaman yang dicairkan, 3) Jaminan pinjaman diikat oleh notaris jika dipandang perlu, 4) Peminjam bersedia usahanya dikunjungi dan dipantau oleh staf kredit, 5) Lama pengembalian pinjaman maksimal 60 (enam puluh) bulan, 6) Balas jasa pinjaman $2 \%$ menurun per bulan, 7) Jasa pelayanan $1 \%$ dari pinjaman yang dicairkan, 8 ) Pinjaman diikutsertakan dalam program JALINAN

\section{B.6 Kredit Konsumtif Umum}

Tujuannya adalah membantu memecahkan masalah keuangan yang dihadapi oleh anggota terutama untuk memenuhi berbagai keperluan konsumtif, seperti pengadaan barang-barang elektronik, pengadaan perabot rumah tangga, biaya berobat anggota keluarga, pendidikan. Syarat-syarat: 1) Memiliki jaminan tabungan yang riil (Simpanan Saham + Simpanan Fini dikurangi sisa pinjaman) sebesar $40 \%$ dari jumlah pinjaman yang dicairkan, 2) Jangka waktu pengembalian maksimal 36 bulan, 3) Plafon pinjaman maksimal Rp. $50.000 .000,-, 4)$ Balas jasa pinjaman 2\% menurun, 5) Jasa pelayanan $1 \%$ dari saldo pinjaman yang dicairkan, 6) Pinjaman diikutsertakan dalam program JALINAN, 7) Jaminan tambahan berupa rumah dan/atau tanah diikat oleh notaris, jika dianggap perlu. Biaya notaris menjadi tanggungan pinjaman.

\section{B.7 Kredit Pendidikan}

Tujuannya adalah Pinjaman ini diberikan kepada anggota untuk membantu membiayai pendidikan ditingkat perguruan tinggi. Syarat-syarat: 1 Melampirkan foto copy kartu keluarga, 2) Anak yang menerima manfaat pinjaman harus anggota CU-KS, 3) Melampirkan buku rekening tabungan pendidikan dan memiliki saldo minimal Rp. 1.000.000,- dan sudah mengendap minimal 1 bulan, 4) Menunjukan bukti tes di perguruan tinggi atau akan menyusun skripsi/tugas akhir, 5) Dicairkan sekaligus, tetapi dibawa pulang sesuai keperluan pendidikan. Sisanya yang belum dibutuhkan saat itu, sementara disimpan di tabungan pendidikan, 6) Diikutsertakan dalam program oleh JALINAN BKCU Kalimantan, 7) Melampirkan catatan biaya pendidikan dari universitas yang bersangkutan dan catatan pembiayaan lainnya yang relevan, 8) Bunga pinjaman $1,8 \%$ menurun perbulan, 9) Jasa pelayanan $1 \%$ dari pinjaman, 10) Pinjaman diberikan atas nama orang tua, 11) Plafon pinjaman maksimal Rp. 50.000.000,-, 12) Jangka waktu maksimal 60 bulan, 13) Jaminan pinjaman (Simpanan saham, setara saham dan jaminan lain bila diperlukan).

\section{Pelayanan Non-Simpan Pinjam}

\section{C.1 JALINAN (Jaminan Perlindungan Kalimantan)}

Santunan Solidaritas Anggota (Tunas) maksimal Rp. 50.000.000,- dengan ketentuan: Usia di bawah 1 tahun maksimal Rp. 5.000.000,- Usia di atas 1 tahun s/d 70 tahun, maksimal Rp. 50.000.000,- dan usia masuk CU 60 tahun ke atas, maksimal sebesar Rp. 10.000.000,-. Perlindungan Piutang Anggota (Lintang) dengan ketentuan: cacat tetap/meninggal dunia maksimal Rp. 150.000.000,- dan Pinjaman lalai di atas 6 bulan tidak dapat mengklaim.

\section{C.2 SOLID}

Iuran Solidaritas Duka sebesar Rp 100.000,- per anggota per tahun. Jika anggota meninggal, ahli waris yang bersangkutan mendapatkan solidaritas kematian sebesar Rp 10.000.000,-. Batas penyetoran SOLID sampai dengan tanggal 31 Maret dalam tahun berjalan. Apabila sampai dengan batas waktu belum disetorkan maka akan ditarik dari simpanan Sufa dan atau simpanan Fini.

\section{C.3 Santunan Rawat Inap (SRI)}

Tujuannya adalah santunan ini diperuntukkan bagi anggota yang sakit dan dirawat inap di Rumah Sakit. Syarat-syarat: 1) Iuran SRI sebesar Rp. 50.000,per anggota per tahun, 2) Klaim SRI maksimal Rp. 500.000,- per tahun per anggota dengan melampirkan bukti (asli) biaya rawat inap dari Rumah Sakit, 3) Sebelum pencairan klaim SRI, Staf Manajemen terlebih dahulu akan melakukan pengecekan ke Rumah Sakit yang bersangkutan, 4) Jika biaya rawat inap melebihi klaim SRI maka kelebihan tersebut menjadi tanggungan anggota yang bersangkutan. Demikian juga jika klaim kurang dari plafon klaim SRI dalam setahun maka tidak dapat diambil, akan diperuntukkan bagi anggota lain yang membutuhkan sesuai perhitungan diatas, 5) Klaim SRI bukanlah jatah setiap anggota yang harus dihabiskan dalam setiap tahun buku, 6) Apabila ditemukannya manipulasi data (nota fiktif) maka akan diberikan sanksi berupa pengembalian klaim sebesar 300\% dan dikeluarkan dari keanggotaan CU Kasih Sejahtera dengan terlebih dahulu membuat perhitungan hak dan kewajiban anggota yang bersangkutan, 7) Batas penyetoran SRI sampai dengan tanggal 31 Maret dalam tahun berjalan. Apabila sampai dengan batas waktu belum disetorkan maka akan ditarik dari simpanan Sufa dan atau simpanan Fini, 8) Klaim dapat diajukan apabila iuran SRI telah mengendap 1 bulan.

\subsection{Peranan Credit Union Kasih Sejahtera Tempat Pelayanan (TP) Kefamenanu bagi petani di Kabupaten TTU}

a. Responden Pegawai

Berdasarkan hasil penelitian, seluruh responden menyatakan bahwa: 1) jenis usaha yang dijalankan oleh Credit Union Kasih Sejahtera adalah Usaha Simpan Pinjam; 2) keunggulan Credit Union Kasih Sejahtera adalah bahwa Credit Union mengandung 3 ciri utama yakni ciri koperasi, ciri bank, dan ciri asuransi; 3 ) setiap anggota termasuk anggota petani yang meminjam pada Credit Union memiliki kemampuan untuk mengembalikan pinjaman. Bahkan anggota yang berlatar belakang profesi sebagai petani cenderung lebih aktif dan tepat waktu dalam mengembalikan pinjaman; 4) ada beberapa kendala yang sering ditemukan dalam proses pengembalian pinjaman diantaranya, apabila anggota yang meminjam tersebut terkena musibah, atau adanya kebutuhan tiba-tiba sehingga penggunaan pinjaman agak melenceng dari tujuan meminjam sebelumnya. Namun Credit Union juga memiliki kebijakan untuk meringankan beban peminjam dengan menunda waktu pengembalian pinjaman selama 1 bulan asalkan peminjam tersebut melaporkan kendala yang dialami serta telah dipastikan kebenarannya melalui pemeriksaan di lapangan oleh staf Credit Union.

Dalam hal alasan penyetujuan pinjaman bagi anggota petani, jawaban responden sangat bervariasi. Dari 10 orang responden, 4 orang atau $40 \% \mathrm{di}$ antaranya menjawab bahwa alasan penyetujuan pinjaman lebih didasarkan pada alasan kemanusiaan bahwa petani adalah termasuk dalam golongan kaum miskin yang harus dibantu karna bagaimanapun juga petani adalah bagian dari Credit Union Kasih Sejahtera yang memiliki hak dan kewajiban yang sama. Sedangkan 6 orang responden atau $60 \%$ diantaranya menjawab bahwa alasan penyetujuan pinjaman lebih didasarkan pada hal-hal yang bersifat teknis yakni apabila peminjam (petani) memenuhi syarat yang ditentukan dan telah disurvey.

b. Responden Petani

Berdasarkan hasil penelitian, dari 10 orang responden, 4 orang di antaranya atau $40 \%$ responden memilih menjadi anggota Credit Union oleh karna sistem pengelolaan yang profesional. Sedangkan 6 orang atau $60 \%$ responden memilih menjadi anggota Credit Union oleh karna kebijakan Credit Union yang memberikan pinjaman dengan bunga yang rendah dan terjangkau. Dari 10 orang responden, 8 orang di antaranya atau $80 \%$ responden menjawab bahwa syaratsyarat untuk meminjam pada Credit Union termasuk mudah dan disanggupi oleh responden. Sedangkan 2 orang atau 20\% responden menyatakan bahwa syarat yang ditetapkan oleh Credit Union termasuk sulit dikarenakan untuk meminjam dalam jumlah yang besar terbentur pada faktor usia mengingat usia responden yang tidak lagi memenuhi syarat untuk melakukan peminjaman. Dari 10 orang responden, 5 orang di antaranya atau $50 \%$ responden meminjam pada Credit Union untuk membiayai pendidikan anak, 3 orang di antaranya atau $30 \%$ responden meminjam pada Credit Union untuk membiayai pembangunan rumah yang layak huni, serta 2 orang atau $20 \%$ responden meminjam pada Credit Union untuk membeli kendaraan bermotor (sepeda motor).

\section{Simpulan}

Credit Union Kasih Sejahtera adalah lembaga keuangan yang menjalankan usaha simpan pinjam serta memiliki 3 ciri utama yang menjadi keunikannya yakni ciri bank, ciri koperasi, serta ciri asuransi. Ada upaya pemberdayaan dari Credit Union bagi petani yang bertujuan untuk mengubah pola pikir petani yang bersifat konsumtif atau boros menjadi petani yang hemat serta mampu mengelola keuangannya secara mandiri dan terarah melalui pendidikan dan pelatihan yang berlangsung secara kontinyu. Produk-produk yang dimiliki oleh Credit Union Kasih Sejahtera bersifat memudahkan serta membantu anggota khususnya petani dalam rangka meningkatkan kesejahteraan serta derajat hidupnya. Peranan nyata Credit Union Kasih Sejahtera bagi petani di antaranya adalah sebagai penyedia dana segar dengan bunga yang rendah sehingga dapat dimanfaatkan oleh petani untuk dapat membiayai pendidikan anak, membangun rumah yang layak huni, serta memenuhi kebutuhan-kebutuhan lainnya. Credit Union juga berperan merubah pola pikir petani agar hidup hemat dan mulai menabung demi masa depan.

\section{Pustaka}

Credit Union, 2010. Panduan Credit Union Kasih Sejahtera Cabang Kefamenanu.

Deprindakop, 2010. Perindustrian dan Koperasi Kabupaten Timor Tengah Utara. Funan, H., 2010. Kajian Kinerja Koperasi Kredit (Kopdit) Sami Jaya Cabang Oetalus Kecamatan Bikomi Selatan Kabupaten Timor Tengah Utara.

Kasmir, 2007. Bank dan Lembaga Keuangan Lainnya. PT. Raja Grafindo Persada, Jakarta.

Nasir, N., 2003. Metode Penelitian. Ghalia Indonesia, Jakarta.

Triandaru, S., Santoso, T., 2006. Bank dan Lembaga Keuangan Lainnya. Salemba Empat, Jakarta. 